\title{
Measuring Effectiveness of Planning and Control
}

\author{
Hamizah Yakob, Fatimah Yusof, Hazlina Hamdan \\ Faculty of Architecture, Planning and Surveying, \\ Universiti Teknologi MARA, Shah Alam, 40450, Malaysia \\ hamizah1204@gmail.com
}

\begin{abstract}
The current planning mechanisms which are development plan and planning control were recognised as important tools in housing planning process. However, the weaknesses involved in the preparation of development plans and its implementation through development control may impose constraints on housing development. The objective of this paper is to evaluate whether the housing planning and control activities practiced require improvement in terms of the level of effectiveness of its implementation by the LPAs and PCs in Selangor using Quadrant Analysis. It was found that three activities; location, compliance and difficulties need high attention to achieve effective housing planning.

Keywords:Effectiveness; Planning and Control Activities; Town Planners; Quadrant Analysis

eISSN: 2398-4295 (C) 2016. The Authors. Published for AMER ABRA by e-International Publishing House, Ltd., UK.. This is an open access article under the CC BY-NC-ND license (http://creativecommons.org/licenses/by-ncnd/4.0/). Peer-review under responsibility of AMER (Association of Malaysian Environment-Behaviour Researchers), ABRA (Association of Behavioural Researchers on Asians) and cE-Bs (Centre for EnvironmentBehaviour Studies), Faculty of Architecture, Planning \& Surveying, UniversitiTeknologi MARA, Malaysia.

https://doi.org/10.21834/ajbes.v1i4.40
\end{abstract}




\subsection{Introduction}

Housing is an important element in the development of a country. Effective housing planning practice can control the development of land use and consequently overcome the issues pertaining to housing mainly in urban areas (Burgess, Monk, \& Whitehead, 2010; Monkkonen, 2013; Rameli, 2009; Yakob, Yusof, \& Hamdan, 2012, 2015). Conversely, ineffectiveness and weaknesses in planning create failure in providing a proper balance of housing supply. As described by Rameli (2009), ineffectiveness of planning system can be seen in each housing planning activities, from forecasting of future housing requirements to the determination of land area for future housing development in the Local Plans. Meanwhile, inefficient development controls process by the local planning authorities in assessing the housing development applications also contribute to the ineffectiveness of planning system (Rameli, 2007). The town planning system involves development plans and development control procedures that comprise of interrelated matters for planning considerations (Osman, Bachok, Bakri, \& Harun, 2014; Mohd, Arbi \& Ramly, 2007). Various planning activities starting from preparation of development plans to implementation through planning control could affect housing provision.

The aim of this study is to identify the planning activities that ensure the effectiveness of housing planning control. In achieving the aim of study, the objectives of the paper is to identify the strengths and weaknesses of the housing planning and control activities in ensuring and improving the effectiveness of the housing delivery system. In addition, this study will use the Quadrant Analysis or Importance- Performance Analysis (IPA) Matrix in identifying the activities that require high attention from the Local Planning Authorities (LPAs) and Planning Consultants (PCs) during the process of housing planning control. This approach provides a comprehensive understanding of the extent of which the housing planning activities are important for improvement based on the level of effectiveness of its implementation. Figure 1 shows indicators of planning mechanisms, which provide valid measurements of the planning and control construct. However, in this paper, only three (3) items were highlighted.

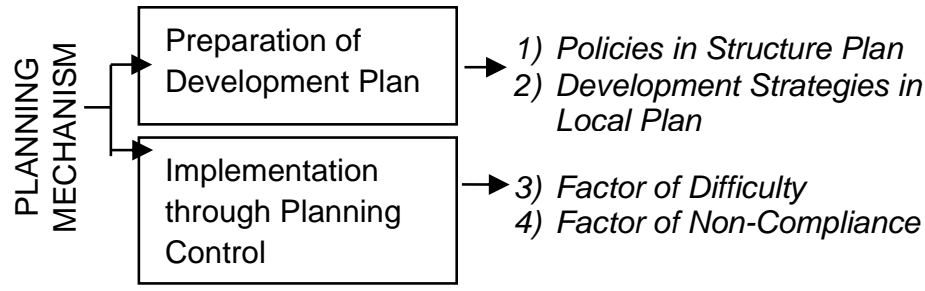

Figure 1: The conceptual pathway between planning and control in housing development. 


\subsection{Literature Review}

\subsection{Determination of Land Location for Housing Development}

Location for future housing development is one of planning activities during the feasibility studies in the housing sector. Rameli (2009) has indicated that following the formulation of housing policies to achieve development objectives, strategies such as determination of housing location could improve the effectiveness of housing planning through some consideration of physical aspects. However, in his study, it was indicated that there is a lack of attention given towards market demand in determining future housing locations. This is supported by Mohd, Arbi \& Ramly (2007) who have claimed that from the housing developers' point of view, the potential of development areas depends upon economic factors such as supply and demand, as well as cost for construction. Also, they argued that land zones for housing developments was designated in development plans without regard for availability of land for the provision of infrastructure and facilities within the housing development.

Consequently, interruptions in progress of housing projects will occur as it involves land dealings for its provision when it comes to implementation (Gurran \& Whitehead, 2011; Yakob, Yusof \& Hamdan, 2012; 2015). On the other hand, Gurran \& Phibbs (2013) argued that it is not necessary to build new development within existing or surrounding housing developments or install new infrastructures to support the development of new areas. It depends on how the builders market their products. Moreover, it has also been claimed that the planning for housing provision in the wrong types and quantity has caused locational mismatches between the supply and demand for housing (Gurran \& Phibbs, 2013). Consistent with theory by Dunse, Thanos \& Bramley (2013), planning policies related to location could focus on types of housing development such as landed or flatted property for areas with limited land supply, mainly in urban areas. Therefore, regardless of the above arguments on weaknesses in the determination of land location, it could still serve as a good indicator in measuring the effectiveness and importance of locational factors for future housing development.

\subsection{Distribution of Land Size for Housing Development}

Similarly, the distribution of land size or land amount is also important in housing planning activities as part of the development strategies in a Local Plan (LP). Housing provision is related to the land amount planned based on forecasting during the technical study for LP. According to Rameli (2009), the effectiveness of the process of planning and controlling of housing supply very much depends on the accuracy of the future housing land area determined by the LP. Other than that, aspects to be considered are ensuring future housing land area figures tally with housing forecast and translated accordingly into the LP proposal map, as well as ensuring housing land zones tally with the actual land required for future housing supply. 
Furthermore, it can also be determined by land acreage, housing quantity, housing types and housing category which depends on the statements of proposals or objectives outlined in the development plans (SP and LP). This is supported by Maliene \& Malys, (2009); Burgess et al., (2010); Gurran \& Whitehead, (2011); Rameli, (2011); Gurran \& Phibbs, (2013) who have claimed that main components in the allocation of future housing land are amount or quantity of new buildings required, intensity of development planned, marketability of land released and housing choices. It was argued that the weaknesses and inaccuracy of distribution of future housing land area leads to housing oversupply (Rameli, 2009). This issue is due to the activity of forecasting of future housing that does not take into account market mechanisms (e.g. effective demand from people) (Mohd, 2011). Furthermore, it has been argued that the determination of future land area does not normally tally with housing forecast. The determination of future housing development by time frame especially in the form of the overall planning period could also contribute to the issue of housing supply.

\subsection{Planning Guidelines for Housing Development}

In the Malaysian context, problems occur in complying with these planning standards and guidelines especially in land sub-divisions and layout plan approval stages (Mohd, Arbi \& Ramly, 2007, Mohd, Ahmad \& Aziz, 2011). These problems are much related to the quantity and size of community facilities required within future housing developments. It was argued that the large land acreage required to provide community facilities limited the number of houses that can be built (Yakob, Yusof \& Hamdan, 2012; Lee \& Wong, 2014). Besides the community facilities, problems also occurred in complying with road designs and widths. The road design depends on the neighbourhood units to be created, and the security measure considered. Fewer number of access points into a housing scheme means better security (Mohd, Arbi \& Ramly, 2007). It was claimed that the requirement to form efficient traffic circulation might defeat the purpose of security measures (Lin \& Meulder, 2012; Mohit, Ibrahim, \& Rashid, 2010; Yakob, Yusof, \& Hamdan, 2012). Also, the cost of land traded for roads would not always be covered by the revenue generated from the sale of the houses based on the market prices.

Other problems and difficulties faced by housing developers are the provision of public utilities such as electrical sub-stations that require a large land area. Without those utilities, the housing scheme concerned could not be implemented. All these planning requirements depend on planning standards about size and quantity. Similarly, the 10 percent provision of open space, as required in guidelines seemed unreasonable in certain cases in which the size, quantity, shape and design affect the development costs. Consequently, it would affect the already limited number of houses that can be built (Mohd, Arbi \& Ramly, 2007; Yakob, Yusof \& Hamdan, 2015). Thus, the level of implementation of these planning guidelines during layout plan approval could significantly affect the level of compliance indirectly. 


\subsection{Level of Compliance during Housing Approval Process}

Planning control implementation in Malaysia was challenged by the issue of noncompliance (Chua \& Deguchi, 2008). According to Rameli \& Aman, (2011), planning control procedures require the LPAs to consider several aspects in controlling housing supply such as compliance to the proposed land use zoning, stipulation of housing development priority areas (development phases), density control, guidelines and current housing policies. Legally, the LPAs may only grant approval if the housing application is within the housing zone. Nevertheless, in practice, there are many cases where approval was still given although the site were planned for other land use activities or located outside the permitted development areas. Also, Rameli (2009), indicated that less attention was given and failure in marking boundaries of housing development priority areas (housing development phases), has discouraged the LPAs to consider this factor.

Compliance with the LCH policies is an aspect of most concern among the LPAs in approving housing applications. However, although Malaysia regulation forces developers to construct LCH according to percentage required in the policy, this is not visible on the ground in some cases (Bakhtyar, Zaharim, Sopian, \& Moghimi, 2013; Yakob,Yusof \& Hamdan, 2013; Foo \& Wong, 2014). In addition, the LPAs also take into consideration several aspects upon receiving an application for planning permissions, such as compliance with Master Plan in LP, types of development allowed, housing category and housing compositions (e.g. in Selangor; 20:20:10 for more than 10 acres and above). Compliance with technical requirements can also be time- consuming for applicants. Sometimes, the application is rejected due to some technical mistakes such as errors in figures, tables, calculations and spelling. However, this is only faced by small scaled, inexperienced or new housing developers (Mohd, Arbi \& Ramly, 2007).

\subsection{Level of Difficulties during Housing Approval Process}

Certain conditions can be imposed before planning approval is given. During the housing approval process, the Town Planning Committee or the State Planning Authority may impose several conditions or items to be included in the proposed layout plan based on the relevant development plans or current planning material. It has been argued that housing planning control seemed to be present the most difficulties during the application and approval process. Among the difficulties highlighted were the application procedure (Mohd, Arby \& Ramly, 2007), correspondence of planning departments (Mohd, Ahmad, \& Aziz, 2009), consultation and discussion (Ahmad et al, 2013), compliance to the planning standards (Chua \& Deguchi, 2008), proposed housing layout design, and the most common problem is related to time for approval (Ball, 2011; Kim,2011).

Moreover, other requirements such as traffic, landscaping, water supply, power supply, building design and environmental controls also contribute to the difficulties faced by developers during housing control process (Rameli \& Aman, 2011; Mohd, Ahmad, \& Aziz, 
2009; Ismail \& Said, 2015). These difficulties could influence evaluation of the level of effectiveness of housing planning and control (Rameli, 2011; Mohd, 2011; Yakob, Yusof \& Hamdan, 2015) which could also be used to generate strategies for developers in dealing with planning constraints (Othman, 2006; Mohd, Arby \& Ramly,2007; Foo \& Wong, 2014). Thus, despite the many planning factors in housing development, it is crucial to identify the importance, strengths and weaknesses of housing planning and control activities through the difficulties that occur during the housing application approval process.

\subsection{Methodology}

Survey methods specifically a face-to-face questionnaire survey, were employed as adapted from Rameli (2009). The respondents for this study were the planners in government and private sectors involved in planning and control activities for housing developments in Selangor. As this study is an expert survey, 67 respondents participated in the survey, who only involved in the preparation of development plans and housing layout plans as well as dealing with housing planning applications and approvals. The respondent chosen are those listed as registered member of Malaysian Institute of Planners (MIP) with total of 38 planners, 15 planners from the local planning authorities (City and Municipal Councils in Selangor) and, 14 planners from the Federal and Selangor State Town Planning and Country Department. This study has limitation as the survey use a single crosssectional method as it is an in- depth examination of one group (planner), which gathered just once within three and a half month (March - July 2014). Therefore, due to time constraint, only those submitted the feedback within the time frame were used as a sample frame. In order to answer a research question, this method was considered sufficient by Sekaran, (2009).

The questionnaire consisted of three main sections. Section 1 contained 10 items, whereas Section 2 was divided into 3 sub-sections that reflect development strategies in Local Plan (LP); Land location (15 items); Land size (11 items) and Guidelines (8 items). Meanwhile, Section 3 was divided into two sub-sections including compliance and difficulty during housing control practice that involved 17 items and 14 items respectively. However, this paper focuses only on Section 2 and 3 from the survey. Descriptive statistics was used to provide an initial description of the sample and followed by an assessment of the validity and reliability of the indicators.

Apart from that, the Importance- Performance Analysis (IPA) Matrix or also known as Quadrant Analysis (QA) was used in identifying the planning and control activities that require high attention for effectiveness in its implementation. It is based on the concept that satisfaction is a result of preferences for service (or activities), and the performance (or effectiveness) is judged by the decision makers and implementers. The respondents were asked to rate planning activities based on its (importance) and the effectiveness (performance) of the selected items in the dimension. This analysis was conducted to 
identify the strengths and weaknesses of housing planning and control activities in ensuring and improving the effectiveness of housing delivery services. Also, it is also important in identifying the aspects or elements or activities that require high attention for improvement to achieve effectiveness of its implementation.

This analysis can be visualized easily from QA plot. The average of importance scores given to the implementation for each item was plotted on a scatter graph to make it easy to understand as shown in Figure 2. The average importance score was plotted on the $x$ - axis while average performance scores were plotted on the $y$-axis for each item measured. From this plot, the areas where there are scopes for improvement were highlighted and identified. The interpretation of the IPA plot is summarised in Figure 2. Quadrant I represents the strength (high importance and high performance); Quadrant II shows the weaknesses (high importance but low performance); Quadrant III contain items of low importance and low performance, hence indicating low priority for improvement and Quadrant IV contains items with low priority, but high performance, indicating over-utilisation of resources.

High Performance

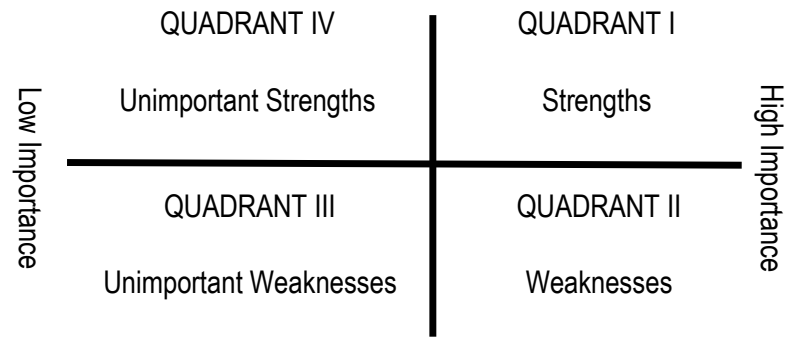

Low Performance

Figure 2: Caption of IPA plot

\subsection{Results And Discussions}

This study offers information on the respondents' perception on the effectiveness of planning and control activities for housing planning and development. Based on these findings, planners either in local planning authorities and consultant firms can establish an action plan to improve planning and control system in the housing industry. This study identified the strengths and the weaknesses that need to be considered by decision makers where it was revealed that the majority of the items or activities were found to be important and effective by the respondents. 
Hamizah Yakob, H., et.al., / Asian Journal of Behavioural Studies, AjBeS 1(4), Nov./ Dec. 2016 (p.11-23)

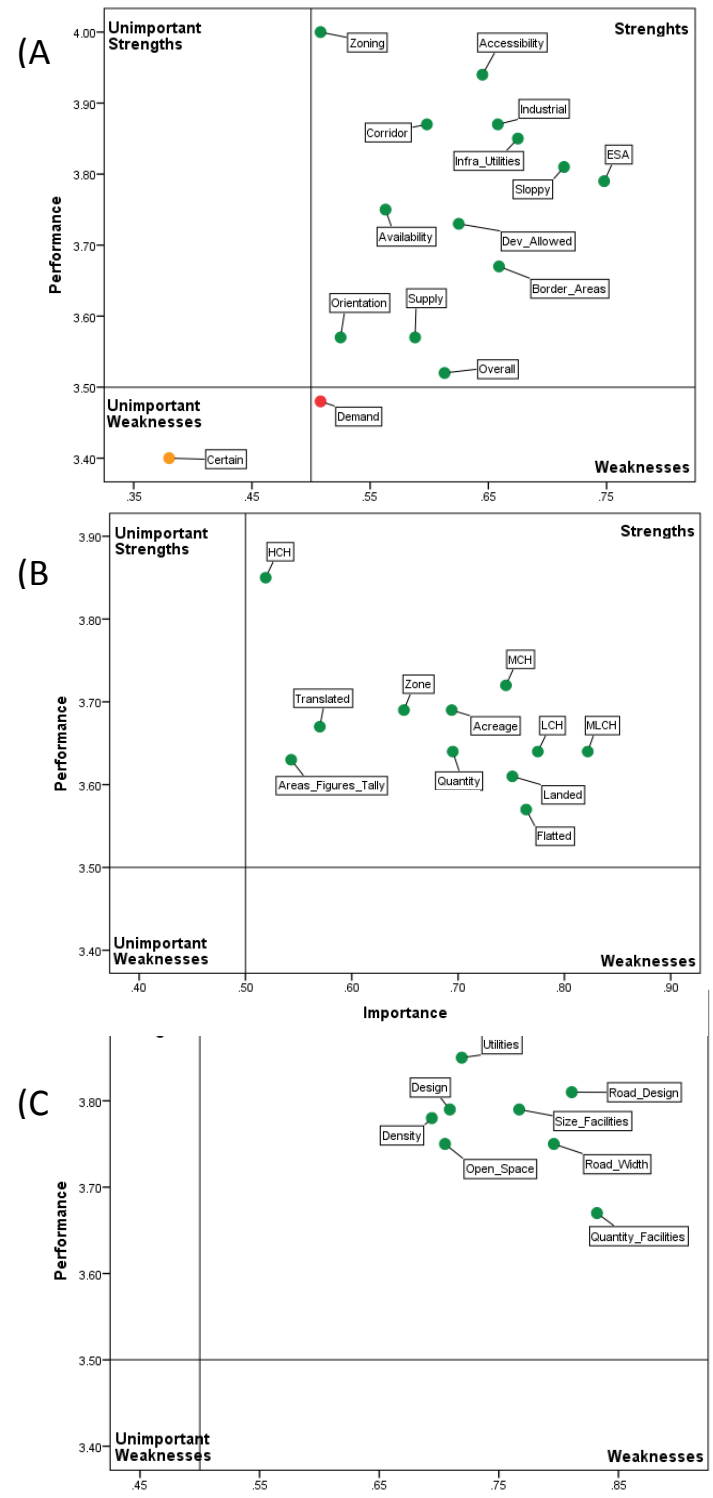

Figure 3. A) IPA Matrix on Land Location; (B) IPA Matrix on Land Size; (C) IPA Matrix on Planning Guidelines 
Two planning activities in development strategies (figure $3 \mathrm{~b}$ ) land size and c) planning guidelines) were considered as the main elements in measuring effectiveness as rated by the respondents. This was found to be in line with a study by Gurran, Gilbert, \& Phibbs, (2013) and Mohd, Ahmad, \& Aziz, (2009) in which it was mentioned that planning activities were found to have significant relationship with respondents' perception towards effectiveness of housing planning and control. Meanwhile, 1 item (figure $3 \mathrm{a}$; "consideration of housing demand") was considered the most important as it identifies current weaknesses in determining land location. This means that the respondent agreed that the item is very important but rated its effectiveness low.

The study also highlights eighteen most crucial items that require serious attentions by planners. The results indicate that fourteen of the items were from factors of difficulties category (figure $4 \mathrm{~b}$ ), three from factors of non-compliance category (figure $4 \mathrm{a}$; low density, high density and development phases), and the remaining were from land location category (figure $3 \mathrm{a}$; consideration of effective housing demand). This result is consistent with the findings from of a previous studies by Mohd, Arby \& Ramly, (2007) and Mohd, Ahmad \& Aziz, (2011), which have argued that development control, especially during an application for planning permission including planning administration, planning evaluation process and requirements of external technical agencies, causes difficulties to housing developers in developing housing estates. Moreover, in relation to land location, Rameli (2009) claimed that consideration to the expected future market demand has not been given enough attention in determining future housing land location.

It is recommended that the future market demands be considered together with physical factors such as accessibility to main roads, the need to follow alignment of development corridor and boundaries. In addition, the aspect of household effective demand are important to be considered and calculated in housing forecast to portray the actual requirements of future housing for certain areas other than total quantity of housing units as seems very appropriate currently. With regards to factors of difficulties and factors of noncompliance, it is suggested that the local planning authorities improve the situation in three aspects, 1) knowledge and expertise in Act 172, 2) planning permission system and 3) planning authorities' resources management. Training conducted for planners and enforcement officers should be assessed and evaluation of One Stop Centre (OSC) should be carried out and improvements made in terms of its effectiveness. Additionally, the local government should find ways to increase financial resources to employ more staff to carry out planning control procedures. 
Hamizah Yakob, H., et.al., / Asian Journal of Behavioural Studies, AjBeS 1(4), Nov./ Dec. 2016 (p.11-23)
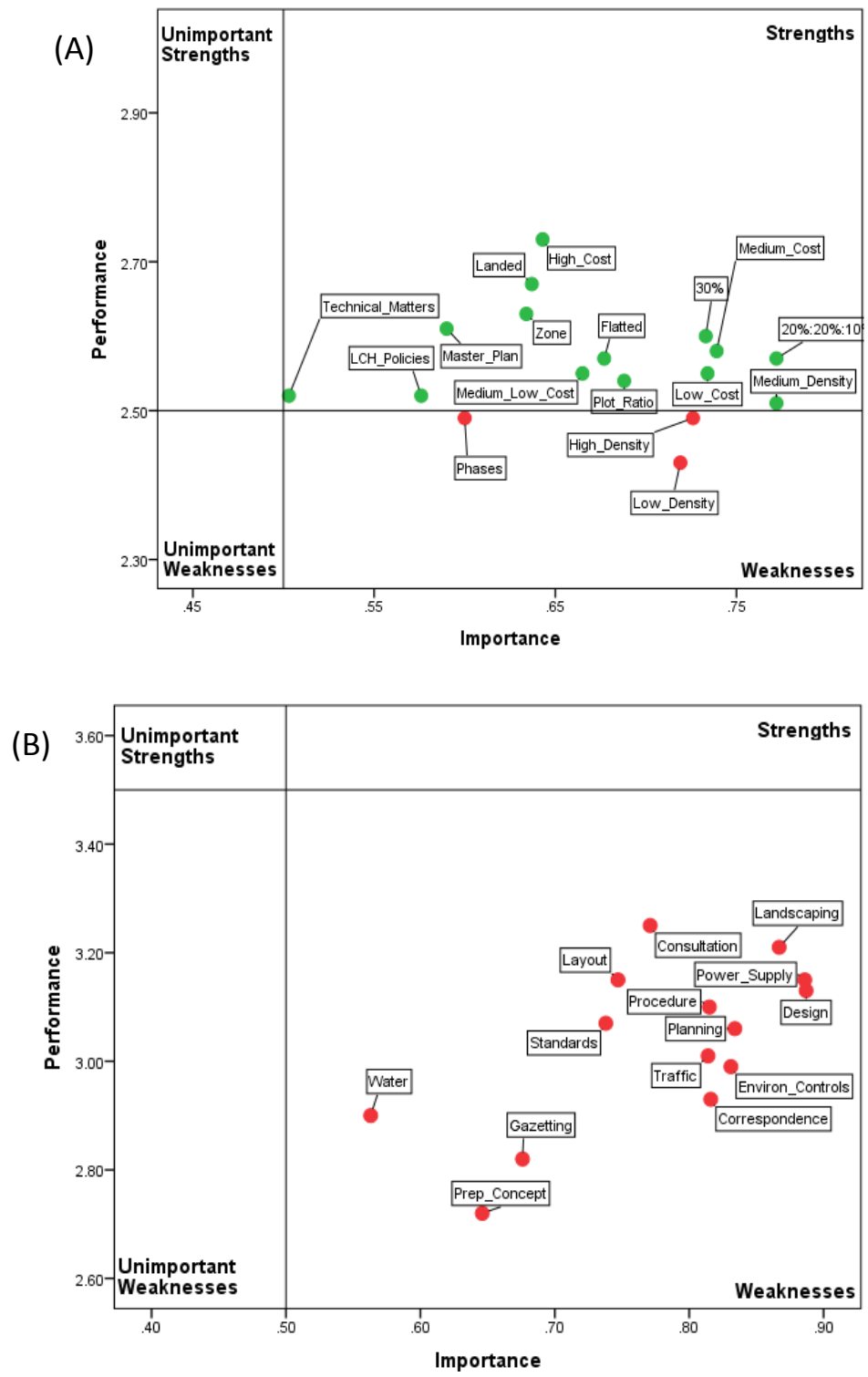

Figure 4. A) IPA Matrix on Level of Compliance; (B) IPA Matrix on Level of Difficulties during Housing Approval 


\subsection{Conclusion}

On the whole, this study demonstrates that the urban housing developments specifically in Selangor, are somewhat influenced by the local planning authorities' activities in implementing planning control, the development plan being the main factor. The results of the analyses claim that main aspects affecting urban housing development consist of housing land location and size, housing guidelines and process of planning applications approval that could be important tools in measuring effectiveness of its implementations. However, there are some limitations faced in this study, and suggestions for future research are significant to address. Research has suggested that there are many other planning factors (e.g. planning decisions and non-planning such as economic factors, land matters and landscape design) that could have some influence on the effectiveness of planning and control activities for housing development. Further investigation on these factors could be carried out. In addition, other than analysis based on perceptions, future studies could be carried out based on content analysis of housing applications records.

This study brings to the fore that the identified factors in housing planning activities must be taken into consideration in implementing forward planning and controlling development to meet housing needs and supply. Hence, policy and decision makers as well as planning authorities must carry out a more vital responsibility in providing better living environment of urban housing through utilisation of town planning mechanisms such as preparing development plans and interpreting it through planning controls.

\section{Acknowledgement}

The author would like to thank the Ministry of Education, Malaysia and Universiti Teknologi MARA (UITM) for providing financial support as well as Centre for Environment- Behaviour Studies (cE-Bs) for the sponsorship for this study.

\section{References}

Ahmad, F., Mohd, I., Maidin, S.L., Zainol, R., \& Mohd Noor, N. (2013). Malaysian development plan system: Issues and problems, one decade after its reform (2001-2011). Journal of Malaysian Institute of Planners, 11, 1-20

Bakhtyar, B., Zaharim, A., Sopian, K., \& Moghimi, S. (2013). Housing for poor people: a review on low- cost housing process in Malaysia.WSEAS Transactions on Environment and Development, 9, 126-136

Ball, M. (2011). Planning delay and the responsiveness of English housing supply. Urban Studies.48 (2), 349 -362. Burgess, G,.Monk, S. \& Whitehead, C. (2010). How can the planning system deliver more housing?. Joseph Rowntree Foundation. 1-8.

Chua, R.S., \& Deguchi, A. (2008). Implementation issues on planning control according to the provision of Town and Country Planning Act 1976 in Malaysia. Journal of Architecture and Urban Design, 14, 47-58 
Dunse, N., Thanos, S. \& Bramley, G. (2013). Planning policy, housing density and consumer preferences. Journal of Property Research.30 (3), 221 -238.

Foo, L. H.R., \& Wong, C. (2014). Planning for housing development in Malaysia: developers' response to the regulatory policy framework. International Planning Studies. 19 (2). 192- 209.

Gurran, N., Gilbert, C. \& Phibbs, P. (2013). Planning and the housing market: measuring regulatory difference and implications for explaining supply and affordability trends. $7^{\text {th }}$ Australasian Housing Researchers' Conference. $6^{\text {th }}$ $8^{\text {th }}$ February 2013

Gurran, N., \& Whitehead, C. (2011). Planning and affordable housing in Australia and the UK: a comparative perspective. Housing Studies. 26 (7-8), 1193- 1214.

Ismail, W \& Said, I. (2015). Integrating the community in urban design and planning of public spaces: a review in Malaysian cities. Procedia Social and Behavioural Sciences. 168. 357-364

Jae, H.K. (2011). Linking land use planning and regulation to economic development: a literature review. Journal of Planning Literature. 26 (1). 35-47

Lin, Y. \& Meulder, B. (2012). A conceptual framework for the strategic urban project approach for the sustainable redevelopment of "villages in the city" in Guangzhou. Habitat International. 3. 380-387

Maliene, V. \& Malys, N. (2009). High- quality housing- a key issue in delivering sustainable communities. Building and Environment Journal. 44 (2). 426-430.

Mohd, I, Ahmad, F. \& Aziz, WA. (2009). Exploiting town planning factors in land development: case study of urban housing in Kuala Lumpur, Malaysia. Journal of Facilities Management. 7 (4), 307 - 318.

Mohd, I, Arby, E. \& Ramly, A. (2007). Urban housing development: town planning issues. Journal of Malaysian Institute of Planners, 43-59.

Mohd, T. \& Alias, G. (2011). The role of housing planning practices in contributing towards housing oversupply. World Academy of Science, Engineering and Technology. 59. 767-775.

Mohit, M., Ibrahim, M. \& Rashid, Y.R. (2010). Assessment of residential satisfaction in newly designed public lowcost housing in Kuala Lumpur, Malaysia. Habitat International. 34 (1). 18-27

Monkkonen, P. (2013). Urban land use regulations and housing markets in developing countries: evidence from Indonesia on the importance of enforcement. Land Use Policy Journal. 34. 255-264

Osman, M, Bachok, S, Bakri, N.I, \& Harun, N. (2014). Government delivery system: effectiveness of local authorities in Perak, Malaysia. Procedia Social and Behavioural Sciences. 153. 452-462.

Othman, A. (2006). Developer's strategies in dealing with planning control: its impact on the urban housing development. Malaysian Journal of Real Estate. 1(2). 7-15.

Rameli. A. (2007). Application of method of content analysis and perception survey in evaluating the effectiveness of planning system in managing housing supply. Proceedings of the $2^{\text {nd }}$ Post Graduate Seminar on Research of Built Environment 2007. March 6. Faculty of Built Environment. Universiti Teknologi Malaysia.

Rameli. A. (2009). Land use planning system and housing development. Ph.D. Thesis. UTM, Malaysia 
Rameli, A. \& Aman, R. (2011). Ineffectiveness of planning control and its implications to housing oversupply. Journal of Civil Engineering and Architecture. 1-15

Yakob, H., Yusof, F., \& Hamdan, H. (2012). Land use regulations towards sustainable urban housing: Klang Valley conurbation. Procedia Social and Behavioural Sciences. 68. 578-589

Yakob, H., Yusof, F., \& Hamdan, H. (2015).Stakeholders' perception on effectiveness of housing planning and control in urban areas: a preliminary survey. Procedia Social and Behavioural Sciences. 168. 289-301. 